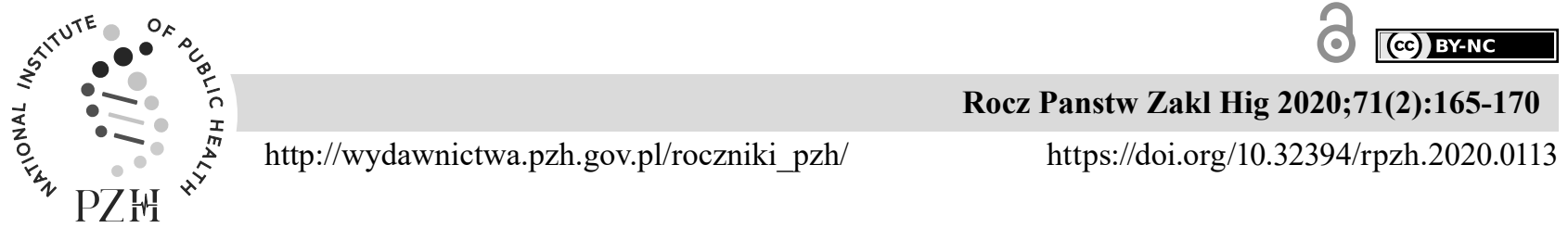

ORIGINAL ARTICLE

\title{
EVALUATION OF BODY MASS INDEX (BMI) OF CHILDREN AGED 7-12 PRIMARY SCHOOL PUPILS IN SIEDLCE
}

\author{
Agnieszka Decyk ${ }^{1}$, Wojciech Kolanowski \\ ${ }^{1}$ Institute of Health Sciences, University of Natural Sciences and Humanities in Siedlce, Poland
}

\begin{abstract}
Background: The occurrence of overweight and obesity in childhood promote many diseases, causing complications both in childchood and in adulthood.

Objective. The aim of study was to evaluate body mass index (BMI) of children aged 7-12 from primary schools in Siedlce (city in Poland) and determining the risk of obesity in this group.

Material and methods. Subjects were 450 primary school children aged 7-12 years living in Siedlce, studied between 2017-2018, and consisted of 269 (59.7\%) girls and 181 boys (40.3\%). The BMIs were determined and total body composition was measured by a SC-240 Analyzer. Result were compared with percentile grids elaborated in the OLAF study.

Results. The average BMI for 7-year-olds was 16.6, (16.8 for girls, c50=15.6 and 16.2 for boys, c50=15.8), whilst for 12-year-olds they were 19.0, (19.7 for girls, $c 50=18$ and 19.1 for boys, $c 50=18$ ). Despite $70.2 \%$ of average BMI values being correct, individually abnormal clusters were observed within the girl and boy grouping. We found that $5.8 \%$ children were underweight (6.7\% girls and $4.4 \%$ boys), whilst $16.7 \%$ were overweight (19.7\% girls and $12.1 \%$ boys), and those obese were $7.3 \%$ (8.2\% girls and $6.1 \%$ boys).

Conclusions. The BMI to height ratio was found to be correct in most subjects, nevertheless it was $12 \%$ higher in boys than girls. Abnormal BMIs were found in 1/3 of children, wherein overweight and obesity were more frequent than those being underweight. Excessive body mass was found in $24 \%$ of all children, with the highest rates being in 9 -year-old girls $(30.2 \%)$ and 12-year-old boys (29.4\%). It is necessary to constantly monitor the BMI among school children.
\end{abstract}

Key words: BMI, children, nutritional status, obesity, overweight.

\section{STRESZCZENIE}

Wprowadzenie: Występowanie nadwagi i otyłości w dzieciństwie zwiększa ryzyko wielu chorób i powikłań zdrowia zarówno w wieku rozwojowym, jak i w wieku dorosłym.

Cel. Celem badań była ocena stanu odżywienia dzieci w wieku 7-12 lat w aspekcie występowania nadwagi i otyłości.

Material i metody. Badania przeprowadzono w latach 2017-2018 wśród uczniów szkół podstawowych w Siedlcach w wieku 7-12 lat. Przebadano 450 dzieci: 269 dziewczynek (59,7\%) i 181 chłopców (40,3\%). Wyznaczono BMI, skład ciała badano metodą elektrycznej bioimpedancji analizatorem Tanita SC-240. Wyniki porównano z siatkami centylowymi z projektu OLAF. Wyniki interpretowano statystycznie.

Wyniki. BMI u dzieci w wieku 7 lat wynosił średnio 16,6 (16,8 dziewcząt c50=15,6; 16,2 chłopy c.50=15,8), a w wieku 12 lat - 19,0 (19,7 dziewcząt c50=18; 19,10 chłopcy c50=18). Mimo prawidłowych średnich wartości BMI (70,2\%), rozkład indywidualny wśród dziewcząt i chłopców ujawnił nieprawidłowości. Niedobór masy ciała stwierdzono u 5,8\% dzieci (6,7\% dziewcząt i 4,4\% chłopców); nadwagę u 16,7\% (19,7\% dziewcząt, 12,1\% chłopców), a otyłość u 7,3\% (8,2\% dziewcząt, $6,1 \%$ chłopców).

Wnioski. Dla większości badanych dzieci wykazano prawidłową proporcją masy ciała do wysokości, jednak w grupie chłopców odsetek ten był wyższy o $12 \%$ niż wśród dziewcząt. Nieprawidłowa masa ciała wstępowała u co trzeciego dziecka w wieku 7-12 lat, przy czym częściej występowała nadwaga i otyłość niż zbyt niska masa ciała. Wśród dzieci z nadmierną masą ciała najwyższy odsetek stwierdzono wśród dziewcząt - 29,4\% i wśród 9 letnich chłopców - 30,0\%. Konieczne jest stałe monitorowanie wskaźnika BMI wśród dzieci szkolnych.

Słowa kluczowe: BMI, Body Mass Index, dzieci, nadwaga, otyłość, stan odżywienia

Corresponding author: Wojciech Kolanowski, Instytut Nauk o Zdrowiu, Uniwersytet Przyrodniczo-Humanistyczny w Siedlcach, ul. Prusa 12,08-110 Siedlce, tel.+4825 6431394, e-mail: wojciech.kolanowski@uph.edu.pl

(c) Copyright by the National Institute of Public Health - National Institute of Hygiene 


\section{INTRODUCTION}

Both overweight and obesity in childhood pose many potential health risks that become manifest as later complications in the formative years and adulthood. There is an increased risk of acquiring metabolic syndrome when excessive fat is accumulated; conditions include hypertension, dyslipidemia, insulin resistance and type 2 diabetes, as well as cardiovascular disease [15]. Nutrition is one of the most important environmental factors that are responsible for psychophysical development in children and adolescents. An adequate diet should be correctly balanced and based on the principles of rational nutrition to ensure that a young body receives the appropriate amounts of energy and nutrients [13]. Schoolchildren are more prone to acquiring inappropriate eating habits when compared to adults. A normal body mass and height are important for maintaining health [5]. Child development is adversely affected by both excessive or deficient daily intakes of dietary nutrients. Any imbalances in the calorific values of consumed food and in energy expenditure can lead to malnutrition, overweight and obesity $[2,18]$.

The study aimed to evaluate the nutritional status of 7-12-year-old children in terms of overweight and obesity.

\section{MATERIALS AND METHODS}

The study was carried out in 2017-2018 on 450 pupils aged 7-12 years attending 2 primary schools in Siedlce; broken down into 269 girls (59.7\%) and 181 boys $(40.3 \%)$. This sample represented $16.6 \%$ of all primary schoolchildren in Siedlce. Ethical approval for the study had been obtained in writing from the Ethics Committee of the University of Natural Sciences and Humanities, together with parental consent for the participants. The basic anthropometric parameters measured were pupils' body height and mass. The body mass was measured by the Tanita SC-240 analyzer at a $0.1 \mathrm{~kg}$ precision, whilst the body height by a SECA 214 stadiometer. The latter was performed on subjects not wearing either shoes or hats, nor having elaborate hairstyles or hair ornamentation. Subjects were required to stand upright with their backs to the height meter so that the head, shoulders, buttocks and heels were touching the device. Hands were loosely laid alongside the body. The ear canal was aligned to the cheekbone. All measurements were taken in the morning and subjects wore sports-kit without any footwear. Enrollment criteria for the study were written consent from the parents or legal guardians, absence of any body-wasting diseases and good health; whereas exclusion criteria were the absence of written consent from parents or legal guardians or if pupils were suffering from any chronic illnesses. Study group characteristics are shown in Table 1 .

Both BMI and body composition were measured using the electrical bioimpedance method of the Tanita SC-240 analyzer which were then compared to OLAF study reference values.

Table 1. Body weight, height and BMI of examined children according to age

\begin{tabular}{|c|c|c|c|}
\hline Age (years) & $\begin{array}{c}\text { Body weight } \\
(\mathrm{kg})\end{array}$ & Height $(\mathrm{cm})$ & BMI \\
\hline 7 & 26.2 & 125.2 & 16.5 \\
\hline 8 & 27.3 & 128.7 & 16.9 \\
\hline 9 & 32.3 & 134.6 & 17.7 \\
\hline 10 & 38.5 & 145.5 & 18.2 \\
\hline 11 & 43.5 & 152.1 & 18.8 \\
\hline 12 & 46.3 & 155.5 & 19.4 \\
\hline
\end{tabular}

Study data were used to calculate the BMI and such results were referenced to OLAF study percentiles. Subjects were defined as being underweight if their BMIs were $\leq$ the 10th centile, whereas ranges for those overweight or obese were respectively 89th-95th centiles and $\geq 95$ th centile; all according to age and gender.

Statistical analysis was performed using Stratasoft Statistica software (verson 12). The level of significance was taken as $\mathrm{p}<0.05$.

\section{RESULTS}

The average BMI, height and the BMI:height ratio were found to lie within the appropriate reference ranges of OLAF study percentiles. Both the average BMI and height for girls were respectively $33.7 \mathrm{~kg}$ and $136.6 \mathrm{~cm}$, whilst they were $34.0 \mathrm{~kg}$ and $137.7 \mathrm{~cm}$ for boys; there being no statistical difference between genders.

Despite observing that $70.2 \%$ of subjects had normal average BMIs, separate clusters could be identified having abnormal results (Diagram 1). We found that $5.8 \%$ children (Table 1$)$ were underweight $(6.7 \%$ girls and $4.4 \%$ boys), whilst $16.7 \%$ were overweight $(19.7 \%$ girls and $12.1 \%$ boys) or obese at $7.3 \%$ (8.2\% girls and $6.1 \%$ boys).

The average BMI for 7-year-olds was 16.5, (16.8 for girls, $c 50=15.6$ and 16.2 for boys, $c 50=15.8)$, for 8 -yearolds 16.9, (17.0 for girls, c50=16.0 and 16.9 for boys, c50 $=16.2$ ), for 9 year-olds this was 17.7 (17.9 for girls, $\mathrm{c} 50=16.4$ and 17.5 for boys, $c 50=16.7)$, for 10 year-olds $18.2(18.5$ girls, $c 50=16.9$ and 18.0 boys, $c 50=17.1)$ and for 11 year-olds 18.8 (18.9 girls, c50=17.5 and 18.7 boys, c50=17.6), whilst for 12 year-olds 19.4 (19.7 girls, $\mathrm{c} 50=18$ and 19.1 boys, $\mathrm{c} 50=18.1$ ). 


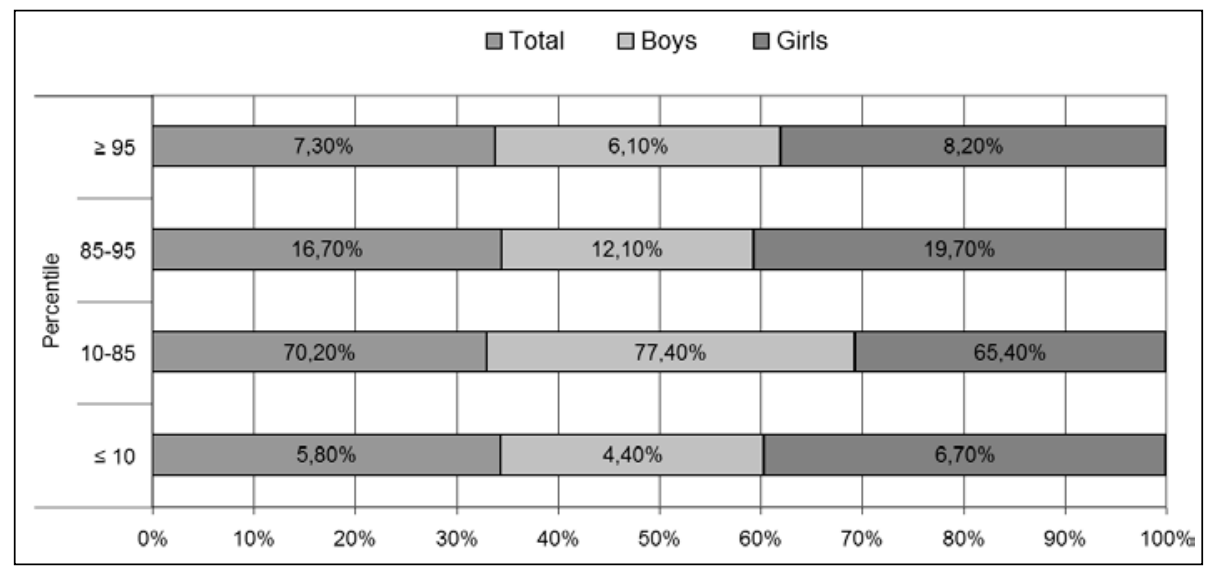

Figure 1. Characteristic of examined children group according to BMI percentile grid ranges

Table 2. Body weight ranges of examined children according to $\mathrm{BMI}$

\begin{tabular}{|l|c|c|c|c|c|c|}
\hline \multirow{2}{*}{ Body weight } & \multicolumn{2}{|c|}{ Girls } & \multicolumn{2}{c|}{ Boys } & \multicolumn{2}{c|}{ Altogether } \\
\cline { 2 - 7 } & $\mathrm{n}$ & $\%$ & $\mathrm{n}$ & $\%$ & $\mathrm{n}$ & $\%$ \\
\hline Underweight & 18 & 6.7 & 8 & 4.4 & 26 & 5.8 \\
\hline $\begin{array}{l}\text { Correct body } \\
\text { weight }\end{array}$ & 176 & 65.4 & 140 & 77.4 & 316 & 70.2 \\
\hline Overweight & 53 & 19.7 & 22 & 12.1 & 75 & 16.7 \\
\hline Obesity & 22 & 8.2 & 11 & 6.1 & 33 & 7.3 \\
\hline
\end{tabular}

Table 3. Mean weight, height and BMI of the examined children

\begin{tabular}{|l|c|c|c|c|c|}
\hline \multicolumn{1}{|c|}{ Parametrs } & $\begin{array}{c}\text { Arithmetic } \\
\text { average }\end{array}$ & Median & Minimum & Maximum & SD \\
\hline Age (years) & 9.1 & 9.0 & 7.0 & 12.0 & 1.8 \\
\hline Body weight $(\mathrm{kg})$ & 33.8 & 31.5 & 18.4 & 88.7 & 11.5 \\
\hline Height $(\mathrm{cm})$ & 136.9 & 134.0 & 111.0 & 187.0 & 14.0 \\
\hline BMI & 17.6 & 16.8 & 12.3 & 33.3 & 3.1 \\
\hline
\end{tabular}

Table 4. Division of the examined group into ranges of percentile grids indicating underweight, correct body weight, overweight and obesity among the examined children according to OLAF BMI percentile grids

\begin{tabular}{|c|c|c|c|c|c|}
\hline \multirow{3}{*}{ Sex } & \multirow{2}{*}{ Age (years) } & \multicolumn{5}{|c|}{ Percentile range } \\
\cline { 2 - 6 } & & $\leq 10$ & $10-85$ & $85-95$ & $\geq 95$ \\
\hline \multirow{3}{*}{ Girls } & 7 & $5.5 \%$ & $65.1 \%$ & $19.3 \%$ & $10.1 \%$ \\
\cline { 2 - 6 } & 8 & $4.8 \%$ & $66.7 \%$ & $19.0 \%$ & $9.5 \%$ \\
\cline { 2 - 6 } & 9 & $2.5 \%$ & $67.5 \%$ & $20.0 \%$ & $10.0 \%$ \\
\cline { 2 - 6 } & 10 & $8.7 \%$ & $65.2 \%$ & $21.7 \%$ & $4.3 \%$ \\
\cline { 2 - 6 } & 11 & $10.3 \%$ & $66.7 \%$ & $17.9 \%$ & $5.1 \%$ \\
\hline \multirow{3}{*}{ Boys } & 12 & $10.8 \%$ & $62.2 \%$ & $21.6 \%$ & $5.4 \%$ \\
\cline { 2 - 6 } & 7 & $3.3 \%$ & $81.7 \%$ & $11.7 \%$ & $3.3 \%$ \\
\cline { 2 - 6 } & 8 & $4.2 \%$ & $79.2 \%$ & $12.5 \%$ & $4.2 \%$ \\
\cline { 2 - 6 } & 10 & $3.1 \%$ & $81.3 \%$ & $12.5 \%$ & $3.1 \%$ \\
\cline { 2 - 6 } & 11 & $8.0 \%$ & $72.0 \%$ & $12.0 \%$ & $8.0 \%$ \\
\hline
\end{tabular}


The mean BMI in boys within the normal range was $77.4 \%$, which was $12 \%$ higher than in girls. The lowest rates of normal BMIs for boys $(64.7 \%)$ were noted in the oldest age group of 12 years, whereas the highest $(81.7 \%)$ were found in those youngest at 7 years. The highest rates of underweight $(8.0 \%)$ were observed in boys aged 10 years, whilst $11.7 \%-12.5 \%$ rates were found boys in the 7-10 years age range; at 12 years, this had increased to $17.6 \%$. Similar BMI findings were observed in obese boys, with those aged 7-9 years lowest at 3.1-4.2\% and those highest aged 11 and 12 years; at respectively $13.0 \%$ and $11.8 \%$.

\section{DISCUSSION}

Developmental abnormalities in youngsters can be rapidly identified when nutritional status is being monitored, thus allowing chances for correction. Diet-related diseases can also likewise be prevented [20]. The data gathered on children's health is used for managing health statistics and as reference for preparing various health programmes and targeted preventative measures. The problems of overweight and obesity in childhood has now become one of the most pressing challenges to public health facing many countries throughout the world [11].

The latest scientific figures confirm that worldwide obesity rates are in no way shrinking, but rapidly rising. A WHO report from January 2018 predicted that the global incidence of obesity in children below 5 years age will increase from 41 million (2016 data) to 70 million by 2025; the 2016 figure of 41 million including both overweight and obesity. Once this problem was considered to be largely confined to affluent countries however, at present, this also concerns middle-low income countries, especially city-dwellers. There has been a $50 \%$ rise in the numbers of overweight 5 -year-olds in Africa since 2000, whilst almost half of children, with either overweight and obesity, came from Asia in 2016 [4].

A PITNUTS sudy from 2016 showed that around $10 \%$ of children aged 1-3 years are overweight or obese, whilst $18.4 \%$ are threatened by these conditions [19]. A COSI study from 2016 demonstrated that this problem affects $1: 3$ of those aged 8 years [16] and is not reduced in the ensuing years. A Poland-wide study by the Institute of Food and Nutrition (IZZ), conducted on 10-16-year-olds, found overweight to be a problem in $1 / 5$ children and was more prevalent amongst boys than girls. Rates of overweight became somewhat reduced at later ages, nevertheless they remained steady at $22 \%$ and $18 \%$ for student boys and girls. Those subjects most affected came from the Mazovian (Mazowsze) and Lodz (Lodz) provinces, whilst those least affected were from the Silesian (Slask) and Holycross (Swietokrzyska) provinces [11].
The report of a WHO from 2016 showed that 39\% adults aged 18 years and above were overweight (39\% men and $40 \%$ women) and that $13 \%$ of the world's population is obese ( $11 \%$ men and $15 \%$ women). From 1975 the obesity epidemic had risen 3-fold up to 2018 [4]. The International Task Force (IOTF) stated that about $10 \%$ children aged 5-17 years have increased body mass and $2-3 \%$ can be classified as obese. It is noteworthy that overweight in Poland during the 1970s was found in less than $10 \%$ school children, whereas rates now stand at over 1:5 (ie. $>22 \%$ ) for overweight and obesity. This situation is even worse for the older population. It is now estimated that respectively $64 \%$ and $49 \%$ of men and women in our country are overweight (BMI>25) [7,9].

One way of assessing nutritional status is by measuring the BMI and determining the weight to height ratio. The presented study has shown that the BMI for the majority of girls and boys was within the normal range (respectively $65.4 \%$ and $77.4 \%$ ). Similar outcomes were observed in a study by Sztandery et al. [17] on 486 primary school pupils from the Maslow and Gorno districts, with average BMIs for girls and boys aged 7-10 years being respectively $68.7 \%$ and $71.1 \%$. This trend continued on for 8 and 9-year-old girls at respectively $66.7 \%$ and $68.05 \%$, however 8 and 9 -year-old boys showed lower than overall average rates. A study by Blaszczyk-Bedenek [3] found that most pupil subjects $(66.8 \%)$ had normal body mass to height ratios. In both girls and boys, heights fell within the 25th and 50th percentile according to the OLAF study centile reference ranges.

Our mean BMI results were not significantly different to the Sztander et al. study [6]. In 7-10-yearold boys, the latter study averages were only $0.4 \%$ higher than in ours. The differences in the BMI means for girls were however greater by $1.5 \%$ in the same age group when compared to ours. Likewise, our study showed that the average BMI for same age boys was similar to the reference values obtained by the Kaluga et al. study [12], however we found significantly higher averages for girls of corresponding ages.

Overweight constitutes a serious problem during child development. This appeared in 1:4 subjects in our study, with overweight in $16.7 \%$ cases $(19.7 \%$ girls and $12.1 \%$ boys) and obesity in $7.3 \%$ (8.2\% girls and $6.1 \%$ boys). Girls aged 10 and 12 years showed the highest overweight rates, whilst for boys this was $17.6 \%$ for 12 -year-olds. Higher rates for boys were observed in a study by Witlowski et al. [20], with $22 \%$ for boys and $18 \%$ for girls in primary school subjects aged 7-12 years; overweight and obesity rates were found highest in 10 -year-old boys at $22.4 \%$ and 9 -year-old girls at $20.6 \%$. Lower values were demonstrated by a $W y k a$ et al. study [21], with respectively $12.4 \%$ and $9.6 \%$ girls and boys being overweight and respectively $5.0 \%$ and 
$3.9 \%$ for obesity in girls and boys. Furthermore, other studies conducted by our group in 2017-2018 have confirmed the notion suggested by other workers that there is a tendency for increasingly higher rates of children with overweight to height ratios in Poland.

Another worrying feature found in children is malnutrition. Malnourished children develop poorly, suffer frequent illness and exhibit learning difficulties. Many of those malnourished show dietary deficiencies in key nutrients required for normal body function. Any normally consumed diet which is unbalanced in its components leads to intake deficiencies in vitamins, minerals, protein and carbohydrate [1]. Whenever such components are lacking in the diet, then chronic long-term health problems will emerge as well as there being adverse day-to-day consequences apparent such as fatigue, apathy, lack of energy and brain function disorders. Occult endocrine disorders are also frequently present, where the first observable signs can for example be menstrual disorders in girls [8]. In our study, endocrine problems were recognised in $5.8 \%$ children ( $6.7 \%$ girls and $4.4 \%$ boys). Malnutrition rates were highest in 10-12-year-old boys (7.4\% and $8.0 \%)$ and in 9 and 8 year-old girls $(9.5 \%$ and $8.6 \%)$. A Malczyk et al. study [14] showed lower rates in 275 pupils aged 7-12 years from the Gogolin district, where $3 \%$ were underweight of whom most were boys than girls; in contrast to our present findings. Much higher rates of underweight were noted in a Silesia province study on 410 children from urban areas; $17.5 \%$ boys and $16.6 \%$ girls [10].

\section{CONCLUSIONS}

1. The majority of the child subjects studied had normal body mass to height ratios, however this was $12 \%$ higher in boys than girls.

2. Abnormal body mass occurred in $1 / 3$ children aged 7-12 years, where underweight and obesity were more frequent than underweight.

3. Overweight was observed in an average of $24 \%$ children, with the highest rates seen in 9-year-old girls $(30.0 \%)$ and 12 year-old boys $(29.4 \%)$.

4. It is recommended that nutritional status be continually monitored in children due to the increasing risks of becoming overweight and obese, so as to allow any anomalies in development to be rapidly identified and to thereby prevent dietrelated diseases.

\section{Conflict of interest}

The authors declare no conflict of interest.

\section{REFERENCES}

1. Aheto J., Keegan T.J., Taylor B.M., Diggle P.J.: Childhood Malnutrition and Its Determinants among Under Five Children in Ghana. Pediatr Perinat Epidemiol. 2015;29:552-561.

2. Bielec G., Goździejewska, A.: Nawyki żywieniowe 11-12-letnich uczniów sportowych klas pływackich na tle nietrenujących rówieśników-badanie pilotażowe. Pediatr Endocrin Diab Metabol. 2018;24:73-81.

3. Błaszczyk-Bębenek E., Żwirska J., Schlegel-Zawadzka M.: Ocena stanu odżywienia dzieci z regionu Małopolski. Probl Hig Epidemiol. 2017;98:381-386.

4. Commission on Ending Childhood Obesity. Report of the Commission on Ending Childhood ObesityWHO, Geneva 2018. https://www.who.int/en/news-room/factsheets/detail/obesity-and-overweight (02.02.2019).

5. Fijatkowski B., Łupińska A., Chlebna-Sokół D:. Ocena objawów klinicznych i nawyków żywieniowych u dzieci w wieku 9-13 lat z niedoborem witaminy D. Endokrynol Ped. 2017;16:269-280.

6. Głębocka A., Kęska A.: Porównanie wybranych elementów stylu życia uczniów w wieku 12 lat z Warszawy i Zamościa. Część I - skład ciała i sposób żywienia. Probl Hig Epidemiol. 2016;97:341-347.

7. Głowacka A, Sawer-SzewczykJ, Drzewoski J, Kasznicki $J .:$ The incidence of some components of the metabolic syndrome in children in medium sized town and rural area in Poland. Clin Diabetol. 2017;6:195-203.

8. Hałacz J., Warechowska M.: Ocena sposobu żywienia dzieci w wieku 10-12 lat na terenie miasta Olsztyna. Pediatr Endocrinol Diabet Metabol. 2015;21:23-31.

9. Jarosz M.: Ogólnopolskie działania w zakresie zwalczania nadwagi i otyłości, ze szczególnym uwzględnieniem dzieci i młodzieży. IŻŻ, Warszawa 2013.

10. Jonczyk P., Potempa M., Kajdaniuk D.: Analiza stopnia odżywienia i zaburzeń odżywiania oraz charakterystyka przyzwyczajeń żywieniowych i aktywności fizycznej wśród dzieci w wieku 6-13 lat uczęszczających do wybranych szkół podstawowych na terenach wiejskich województw śląskiego i opolskiego. Pediatr Med Rodz. 2016;12:177-193.

11. Kędzior A., Jakubek-Kipa K., Brzuszek M., Mazur A.: Trendy w występowaniu nadwagi i otyłości u dzieci na świecie, w Europie i w Polsce. Pediatr Endokrynol. 2017;16:41-48.

12.Kułaga Z., Różdżýska A., Palczewska I., Grajda A., Gurzkowska B., Napieralska E., Litwin M.: Siatki centylowe wysokości, masy ciała i wskaźnika masy ciała dzieci i młodzieży w Polsce - wyniki badania OLAF. Stand Med Pediatr. 2010;7:690-700.

13. Malczyk E.: Ocena stanu odżywienia młodzieży z nyskich szkół ponadgimnazjalnych. Probk Hig Epidemiol. 2016;97(3):261-267.

14. Malczyk E.: Stan odżywienia dzieci i młodzieży $\mathrm{w}$ Polsce na podstawie piśmiennictwa $\mathrm{z}$ ostatnich 10 lat (2005-2015). Ann Acad Med Siles. 2016;70:56-65. 
15.Myszkowska-Ryciak J.: Wpływ czynników środowiskowych na pojadanie u dzieci w wieku przedszkolnym. Pomeran. J Life Sci. 2018;64:74-78.

16. Stalmach M.: Polskie badania populacyjne u dzieci, młodzieży i młodych dorosłych: COSI - Childhood Obesity Surveilance Initiative-8-latki w badaniu WHO. Konferencja „Czy to już epidemia otyłości w Polsce? Dynamika nadwagi i otyłości w cyklu życia - wyniki polskich badań populacyjnych u dzieci, młodzieży i młodych dorosłych", Instytut Matki i Dziecka i Instytut Kardiologii im. Prymasa Tysiąclecia Stefana Kardynała Wyszyńskiego, Warszawa; 2018.

17. Sztandera P., Szczepanowska-Wołowiec B., Kotela I.: Evaluation of nutritional status among children aged 7-10. J Edu Health Sport. 2017;7: 197-208.

18. Toledo-Corral C.M., Alderete T.L., Hu H.H., Nayak K., Esplana S., Liu T., Goran M.I., Weigensberg M.J.: Ectopic fat deposition in prediabetic overweight and obese minority adolescents. J Clin Endocrinol Metab. 2013;98:1115-1121.

19. Weker H., Barańska M., Riahi A., Strucińska M., Wiech M., Rowicka G., Dylag H., Socha P.: Nutrition of infants and young children i Poland - PITNUTS 2016. Dev Period Med. 2017;21(1):13-28.

20. Witkowska M., Lesiów T.: Występowanie nadwagi i otyłości wśród dzieci w wieku od 10 do 13 lat w mieście i gminie Ostrzeszów. Nauki Inż Technol. 2014;3(14):51-73.

21. Wyka J., Mazurek D., Broniecka A., Piotrowska E., Borowska M., Biernat J.: Stan odżywienia młodzieży w wieku 13-15 lat w aspekcie zagrożenia zespołem metabolicznym (ZM). Bromat Chem Toksykol. 2013;47: 32-40.

Received: 10.03 .2020

Accepted: 08.04 .2020 